\title{
Evaluasi Keselamatan Operasional Penerbangan dan Potensi Penambahan Rute di Bandara Sam Ratulangi Manado
}

\author{
Halim Prasetyo Hutomo dan Ervina Ahyudanari \\ Departemen Teknik Sipil, Institut Teknologi Sepuluh Nopember (ITS) \\ Corresponding Author: ervina@ce.its.ac.id
}

\section{ARTIKEL INFO}

\section{Informasi Artikel}

Artikel masuk :

Artikel revisi :

Artikel diterima :

\begin{abstract}
ABSTRAK
Bandara sam Ratulangi berlokasi di Kota Manado Provinsi Sulawesi Utara. Evaluasi yang dilakukan terhadap ini adalah evaluasi panjang dan lebar runway, evaluasi kawasan keselamatan operasi penerbangan terhadap topografi, dan evaluasi pola pergerakan pesawat terhadap topografi. Selain itu dilakukan juga evaluasi kapasitas dan berat masingmasing pesawat terbang yang beroperasi berkaitan dengan penentuan jarak tempuh optimum pesawat yang digunakan untuk penentuan potensi rute tambahan. Terdapat 4 kesimpulan dalam Studi ini. Pertama, Untuk pesawat kritis Boeing 737 - 900, runway yang tersedia di Bandara Sam Ratulangi Manadomasih memenuhi dimana TORA pesawat Boeing 737 900 adalah $2580 \mathrm{~m}$ dan lebar runway dibutuhkan sesuai kriteria pesawat adalah $45 \mathrm{~m}$. Sedangkan panjang runway yang tersedia adalah $2650 \mathrm{~m}$ dengan lebar $45 \mathrm{~m}$. Kedua, untuk evaluasi KKOP terhadap topografi, pada potongan memanjang topografi bandara masih memenuhi batasan KKOP. Sedangkan pada potongan melintangnya, terdapat topografi dimana ketinggiannya melebihi batas KKOP. Ketiga, pola pergerakan pesawat Boeing 737 - 900 tidak mengalami gangguan saat melakukan lift off. Sehingga untuk pola pergerakan pesawat selanjutnya tidak terjadi gangguan keselamatan operasi penerbangan akibat topografi. Sampai saat ini, Pesawat Boeing 737 - 900 beroperasi dengan jarak tempuh paling jauh 1790 nautical miles yaitu dari Bandara Sam Ratulangi Manado menuju Bandara Shanghai Pudong Tiongkok dengan konsumsi bahan bakar sebesar 18475.60 liter. Dari hasil jarak tempuh optimum yang bisa ditempuh pesawat diperoleh untuk jarak tempuh optimum pesawat Boeing 737 - 900 adalah $3544 \mathrm{~km}$ atau 1920 nautical miles dengan konsumsi bahan bakar sebesar 18720 liter.
\end{abstract}

\section{PENDAHULUAN}

Bandara Sam Ratulangi Manado digunakan oleh 8 maskapai penerbangan yaitu Garuda Indonesia, Lion Air, Sriwijaya Air, Wings Air, Citilink, Batik Air, Nam Air dan Silk Air. Dari 8 maskapai tersebut, terdapat 7 jenis pesawat yang beroperasi, yaitu Airbus A 320, Boeing 737 - 900, Boeing 737 - 800, Boeing 737 - 500, Bombardier CRJ - 1000 ER, ATR 42, dan ATR 75 (Angkasa Pura I). Bandara Sam Ratulangi mampu melayani 20 destinasi, dengan destinasi terjauh adalah Bandara Sam Ratulangi Manado - Bandara Internasional Shanghai Pudong yaitu 1790 nautical miles $(3.330 \mathrm{~km})$. sampai saat ini, Pesawat terbesar yang beroperasi di Bandara Sam Ratulangi adalah Boeing 737 - 900. Panjang runway Sam Ratulangi adalah 2650 m dengan lebar $45 \mathrm{~m}$. Untuk dapat beroperasinya pesawat yang lebih besar dan jarak tempuh yang lebih jauh, dibutuhkan penambahan panjang runway sebagai salah satu faktor pendukungnya.
Bandara Sam Ratulangi terletak $15 \mathrm{~km}$ di sebelah uatara dari Kota Manado dengan ketinggian (elevasi) 265 $\mathrm{ft}$ dpl (83 m dpl). Secara geografis, Bandara Sam Ratulangi dikelilingi pegunungan, di daerah tenggara terdapat Gunung Klabat dengan ketinggian $6.549 \mathrm{ft}$, di daerah barat daya terdapat Gunung Soputan dengan ketinggian $4.600 \mathrm{ft}$, dan di daerah barat terdapat Gunung Manado Tua dengan ketinggian $2.628 \mathrm{ft}$.

Pada tahun 2016 jumlah penumpang di bandara Sam Ratulangi sudah mencapai 2.488.662 penumpang domestik dan 96.204 penumpang internasional (Angkasa Pura I, 2017). Sebanyak 422 pesawat rute internasioal mendarat di Bandara Sam Ratulangi Manado sepanjang Jnuari hingga awal Oktober 2017. Lion Air mendominasi dengan 241 penerbangan, Silk Air 152 penerbangan dan Citylink 6 penerbangan [1]. Pada Juli 2016, jumlah wisatawan asing naik 312,82 persen dari 1.427 menjadi 5.148 orang Hal ini dikarenakan sejak Juli 2016 terdapat penerbangan langsung Manado - Tiongkok. Secara 
Tabel 1. Karakteristik Pesawat Boeing $737-900$

\begin{tabular}{lr}
\hline \multicolumn{2}{c}{ Karakteristik Pesawat } \\
\hline Modul Pesawat & Boeing $737-900$ \\
Panjang (m) & $42.1 \mathrm{~m}$ \\
Lebar Sayap (m) & $34.3 \mathrm{~m}$ \\
$\begin{array}{l}\text { OMGWS (Outer Main Gear Wheel Span }) \\
(\mathrm{m})\end{array}$ & \\
MTOW (Maximum Take-Off Weight) $(\mathrm{kg})$ & $9.0 \mathrm{~m}$ \\
ARFL (Aerodrome Reference Field Length) & $79015 \mathrm{~kg}$ \\
$(\mathrm{~m})$ & $2256 \mathrm{~m}$ \\
Operation Empty Weight $(\mathrm{kg})$ & $42490 \mathrm{~kg}$ \\
Kapasitas Penumpang & 177 \\
Kapasitas Bahan Bakar & $26030 \mathrm{liter}$ \\
ARC (Aerodrome Reference Code) & $4 \mathrm{C}$ \\
\hline Sur An
\end{tabular}

Sumber :Annex 14, ICAO

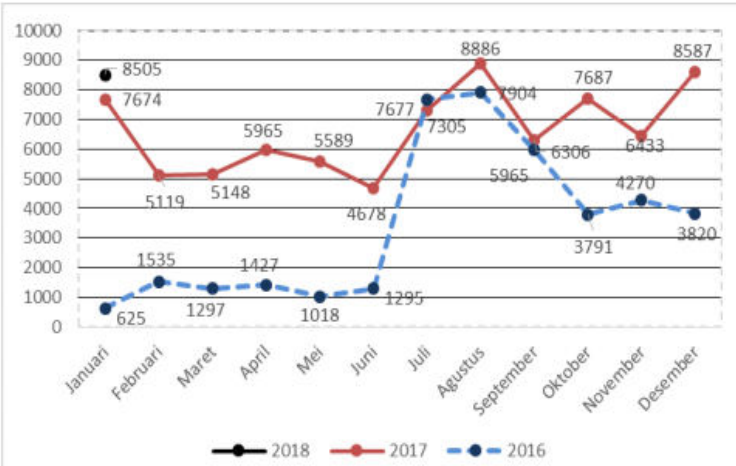

Gambar 1. Jumlah Pengunjung wisatawan mancanegara di provinsi Sulawesi Utara bulan Desember dan Januari dalam dua tahun terakhir (Orang).

Sumber : BPS Kota Manado, 2018.

keseluruhan di tahun 2016, tercatat 61.87 turis ke Sulawei Utara dengan didominasi turis asal Tiongkok China.

Sampai saat ini wisatawan dari Tiongkok, China masih mendominasi dikarenakan adanya rute penerbangan langsung Manado - Tiongkok. Untuk meningkatkan wisatawan dari berbagai penjuru dunia, cara seperti penambahan rute penerbangan langsung memang diperlukan. Oleh karena itu perlu diadakannya analisis tentang potensi penambahan rute yang dapat beroperasi di Bandara Sam Ratulangi Manado (Gambar 1) .

Rumusan permasalahan yang akan dibahas dalam Studi ini, antara lain sebagai berikut.

1. Bagaimana kesesuaian panjang dan lebar runway dengan jenis pesawat yang beroperasi?

2. Bagaimana kesesuaian Kawasan Keselamatan Operasi Penerbangan (KKOP) dengan topografi wilayah sekitar bandara Sam Ratulangi?

3. Bagaimana kesesuaian pola pergerakan masingmasing pesawat yang beroperasi dengan topografi di Bandara Sam Ratulangi?

4. Bagaimana potensi rute pelayanan penerbangan langsung yang bisa dibuka di bandara Sam Ratulangi?

\section{METODOLOGI}

Metodologi yang digunakan dalam penyusunan Studi ini dapat dilihat pada Gambar 2.

\section{A. Variabel Penelitian}

Sebelum melakukan proses identifikasi tema wisata budaya dan sejarah di Kota Surabaya, terlebih dahulu menentukan variabel yang berasal dari kajian pustaka. Variabel yang didapatkan untuk mengidentifikasi tema

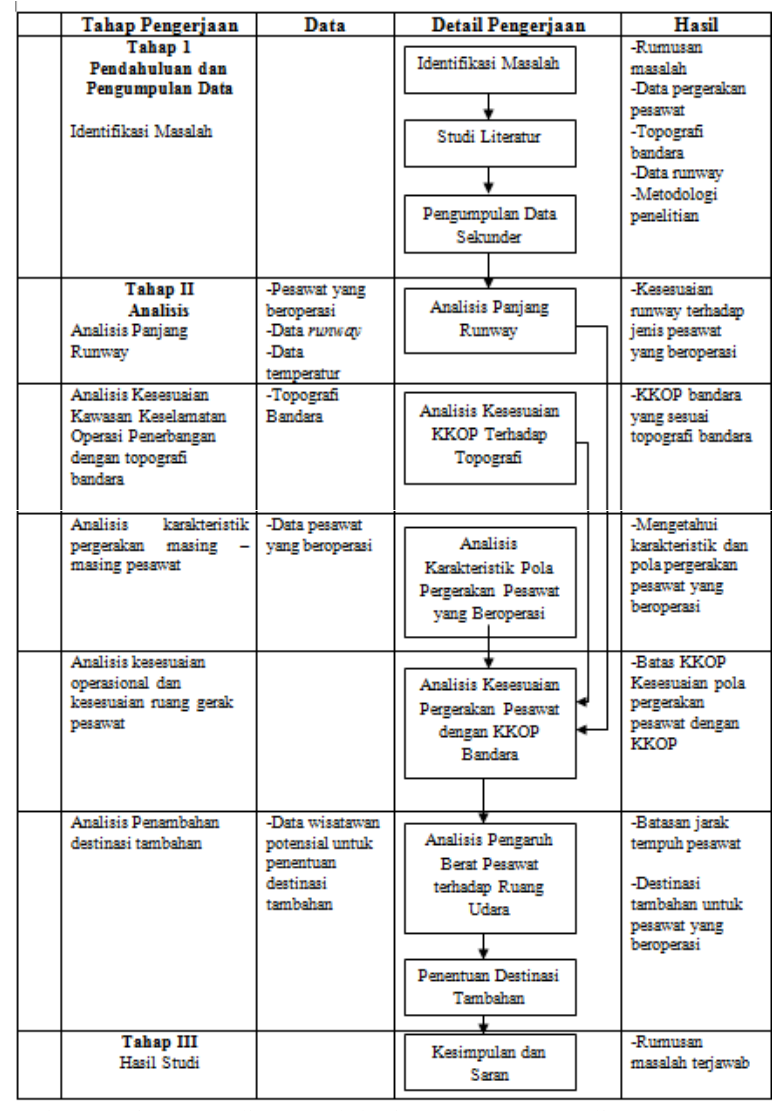

Gambar 2. Diagram Alir Metodologi Penyusunan Studi.

wisata budaya dan sejarah di Surabaya yaitu dari daya tarik budaya, sejarah, dan keberagaman atraksi setiap DTW yang ada.

\section{HASIL DAN PEMBAHASAN}

\section{A. Analisis Panjang dan Lebar Runway}

Dalam analisis ini, panjang dan lebar runway harus diketahui untuk menentukan kawasan keselamatan operasional penerbangan. Dari data data pergerakan pesawat di Bandara Sam Ratulangi, diketahui bahwa pesawat kritis yang beroperasi pada runway Bandara Sam Ratulangi adalah Boeing 737 - 900 (Tabel 1). Data karakteristik runway Bandara Sam Ratulangi Manado dapat dilihat pada Tabel 2.

Panjang runway aktual yang dibutuhkan pesawat yang beroperasi di Bandara Sam Ratulangi didapatkan dengan melakukan beberapa koreksi, diantaranya:

1. Koreksi faktor elevasi,

2. Koreksi terhadap temperatur,

3. Koreksi terhadap slope runway.

Untuk menghitung faktor koreksi, terlebih dahulukan harus mencari nilai ARFL. ARFL adalah panjang landasan minimum bagi pesawat untuk take off pada keadaan standar, yaitu pada kondisi MTOW, ketinggian nol, kondisi atmosfer standar, keadaan tanpa angin, dan kemiringan runway nol. Adapun ARFL pesawat B 737900 adalah $2256 \mathrm{~m}$. Perhitungan koreksi terhadap runway berdasarkan ARFL dan data karakteristik runway adalah sebagai berikut:

1. Koreksi Terhadap Elevasi

$$
\begin{gathered}
\mathrm{KE}=(\text { ARFL } \times \\
+\mathrm{ARFL}
\end{gathered}
$$


Tabel 2. Karakteristik Landas Pacu Pesawat

\begin{tabular}{lc}
\hline \multicolumn{2}{c}{ Karakteristik Runway } \\
\hline Arah Runway & $18 / 36$ \\
Panjang Runway (m) & $2650 \mathrm{~m}$ \\
Lebar Runway & $45 \mathrm{~m}$ \\
Elevasi runway & $18=274 \mathrm{ft} \mathrm{dpl}$ \\
& $36=270 \mathrm{ft} \mathrm{dpl}$ \\
Suhu rata - rata ${ }^{0} \mathrm{C}$ & 26.7 \\
Slope runway \% & 0.15 \\
\hline
\end{tabular}

\begin{tabular}{ccccccc}
\hline \multicolumn{7}{c}{ Tabel 3. Lebar Runway Berdasarkan Code Number } \\
\hline Code & & \multicolumn{5}{c}{ Code Letter } \\
Number & A & B & C & D & E & F \\
\hline $1 \mathrm{a}$ & $18 \mathrm{~m}$ & $18 \mathrm{~m}$ & $23 \mathrm{~m}$ & - & - & - \\
2 & $23 \mathrm{~m}$ & $23 \mathrm{~m}$ & $30 \mathrm{~m}$ & - & - & - \\
3 & $30 \mathrm{~m}$ & $30 \mathrm{~m}$ & $30 \mathrm{~m}$ & $45 \mathrm{~m}$ & - & - \\
4 & - & - & $45 \mathrm{~m}$ & $45 \mathrm{~m}$ & $45 \mathrm{~m}$ & $60 \mathrm{~m}$ \\
\hline
\end{tabular}

Sumber: SKEP 77-VI-2005

Tabel 4. Sistem Navigasi Bandara Sam Ratulangi

\begin{tabular}{ccc}
\hline BANDARA - SAM RATULANG & & \\
\hline NDB & NAUTEL & 1988 \\
DVOR & AWA & 1992 \\
DME & AWA & 1992 \\
ILS - LOC & WILCOX MK-20 A & 2002 \\
ILS - GP & WILCOX MK-20 A & 2002 \\
ILS - OM & &
\end{tabular}

Sumber : AirNav Indonesia

$$
\begin{array}{ll}
\mathrm{KE} & =\left(2256 \times 7 \% \times \frac{80.5}{300}\right)+2256 \\
\mathrm{KE} & =2298.38 \mathrm{~m}
\end{array}
$$

2. Koreksi terhadap Elevasi Temperature (KET)

$\mathrm{KET}=[\mathrm{KE} \times($ temperatur $-(15-0,0065 h))] \times 1 \%+$ $K E$

$\mathrm{KET}=[2298.3 \times(26.7-(15-0,0065 \times 80.5))] \times 1$ $\%+2298.38$

$\mathrm{KET}=2579.32 \mathrm{~m}$

3. Koreksi terhadap Elevasi, Temperatur dan Slope

KETS $=[$ KET $\mathrm{x}$ slope $\mathrm{x} 10 \%]+\mathrm{KET}$

$\mathrm{KETS}=[2579.32 \times 0.15 \% \times 10 \%]+2579.32$

$\mathrm{KETS}=2580 \mathrm{~m}$

Sehingga didapatkan panjang runway aktual atau TORA (Take-off Run Available)untuk pesawat Boeing 737 - 900 adalah $2580 \mathrm{~m}$. Sedangkan panjang runway yang tersedia saat ini adalah $2650 \mathrm{~m}$. Sehingga untuk pesawat dengan ARFL 2256 dapat menggunakan runway Bandara Sam Ratulangi Manado.

Pesawat paling besar yang beroperasi di Bandara Sam Ratulangi Manado adalah pesawat Boeing 737-900 dengan karakteristik yang tertera pada tabel4.4. nilai ARC pesawat Boeing 737 - 900 adalah 4C. Dari Tabel 3 dapat diketahui lebar runway adalah $45 \mathrm{~m}$ [2].

Sehingga untuk golongan 4C, landasan dengan lebar $45 \mathrm{~m}$ masih sesuai kriteria.

\section{B. Analisis Kawasan Keselamatan Operasi Pernerbangan (KKOP) dengan Topografi}

Analisis ini bertujuan untuk mengetahui kesesuaian kawasan keselamatan operasi penerbangan (KKOP) terhadap topografi sekitar Bandara Sam Ratulangi Manado. Hasil dari analisis ini diharapkan dapat diketahui apakah topografi sekitar Bandara Sam Ratulangi Manado tidak mengganggu kawasan keselamatan operasi penerbangan (KKOP) Bandara Sam
Tabel 5. Dimensi KKOP Berdasarkan Klasifikasi Runway.

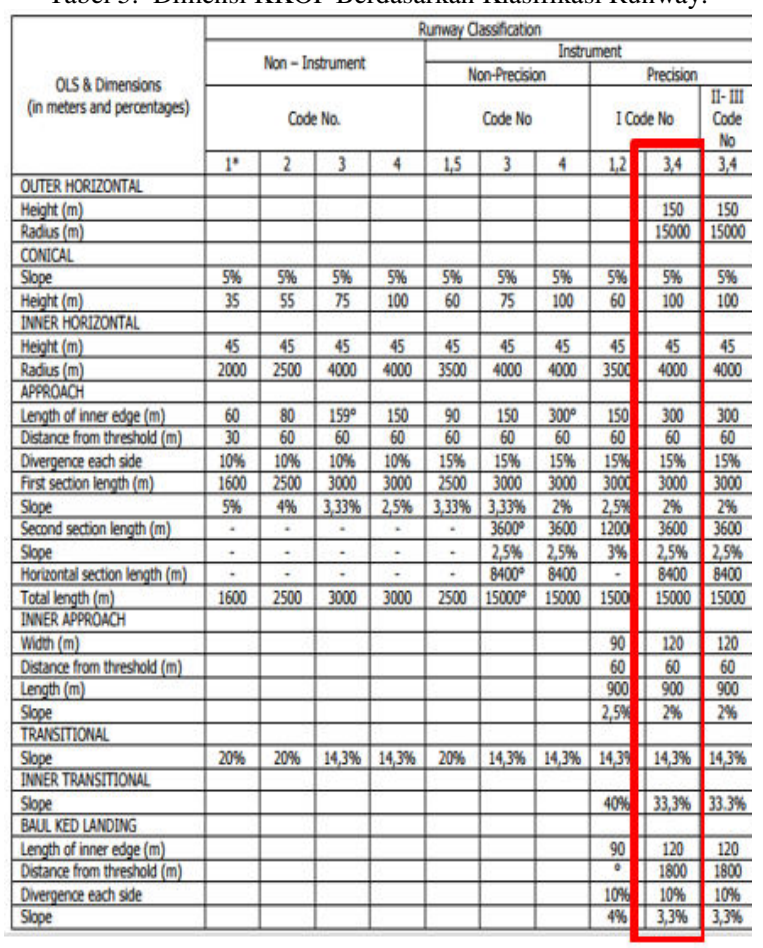

Sumber : SKEP 77-VI-2005

Ratulangi Manado sehingga keselamatan operasional penerbangan masih dapat terpenuhi.

Penentuan KKOP Bandara Sam Ratulangi berdasar pada Peraturan Direktur Jenderal Perhubungan Udara Nomor SKEP/76/IV/2005. Berdasarkan Air Nav Indonesia, Bandara Sam Ratulangi sudah menggunakan sistem navigasi ILS kategori I, sehingga digunakan desain Precision Approach Runway. (Tabel 4)

Berdasarkan Peraturan Direktur Jenderal Perhubungan Udara Nomor SKEP/ 77 / VI /2005, Tabel 5 merupakan batas KKOP bedasarkan klasifikasi runway [3].

Untuk desain Bandara Sam Ratulangi, digunakan Precision Approach Runways dengan pesawat kritis kategori 4C, spesifikasi KKOP disesuaikan dengan ketentuan pada Tabel 3. Kawasan keselamatan operasi penerbangan terdiri dari kawasan berikut:

1. Kawasan Pendekatan Lepas Landas (Approach)

2. Kawasan Kemungkinan Bahaya Kecelakaan

3. Kawasan di bawah permukaan horizontal dalam

4. Kawasan di bawah permukaan horizontal luar

5. Kawasan di bawah permukaan kerucut

Kawasan keselamatan operasi penerbangan tersebut dibatasi oleh batas-batas sesuai pada kriteria tabel 5 dan dapat digambarkan secara keseluruhan pada Gambar 3.

Batas ketinggian KKOP dan elevasi topografi pada potongan memanjang dan melintang KKOP dapat digabungkan sehingga dapat diketahui dengan jelas kenampakan KKOP terhadap topografi Bandara Sam Ratulangi Manado. Pada Gambar 3 dan Gambar 4 merupakan potongan memanjang dan melintang yang tergambar dari hasil evaluasi KKOP dan topografi. Pada Gambar 3 menunjukkan bahwa elevasi topografi tidak melebihi batas ketinggian KKOP Bandara Sam Ratulangi. Pada Gambar 4 menunjukkan bahwa elevasi topografi melebihi batas KKOP Bandara Sam Ratulangi.

Selain topografi yang melebihi batasan ketinggian pada potongan melintang KKOP, juga terdapat bangunan 


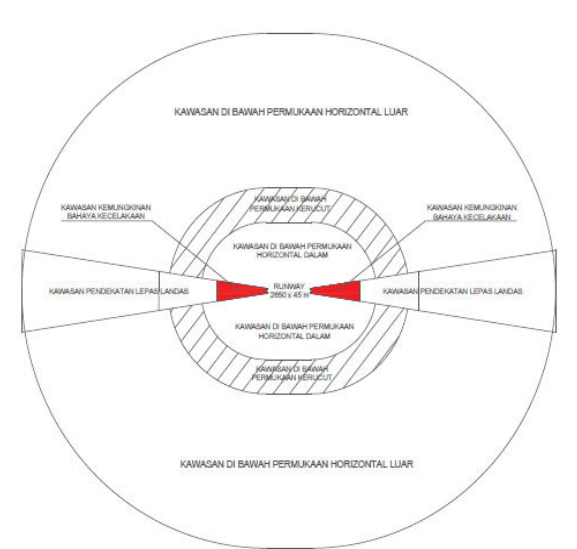

Gambar 3. Kawasan keselamatan operasi penerbangan.

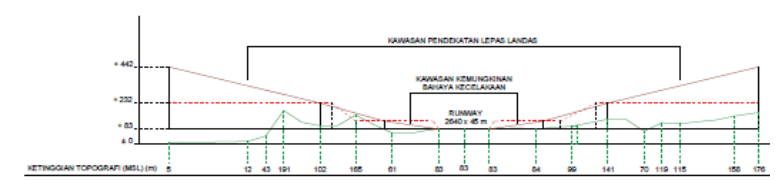

Gambar 4. Potongan Memanjang KKOP terhadap Topografi. (Garis berwarna hijau adalah kontur topografi dan garis berwarna merah adalah batas KKOP).

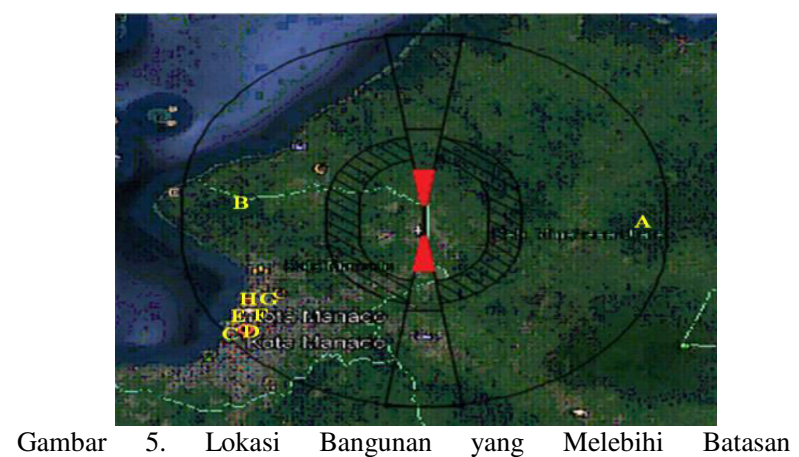

Ketinggian KKOP.

yang melebihi batas ketinggian. Lokasi dan daftar bangunan tersebut dapat dilihat pada Gambar 5 dan Tabel 6.

Berdasarkan Peraturan Menteri Perhubungan KM No 44 Tahun 2005 tentang pemberlakuan SNI 03-7112-2005 [4], solusi untuk bangunan atau sesuatu benda yang melebihi batas ketinggian dan berpotensi membahayakan keselamatan operasi penerbangan harus diberi tanda atau dipasangi lampu. Pemberian tanda atau pemasangan lampu termasuk pengoperasian dan pemeliharaannya dilaksanakan oleh dan atas biaya pemilik atau yang menguasinya.

\section{Analisis Pola Pergerakan Masing-masing Pesawat}

Analisis ini bertujuan untuk mengetahui pola pergerakan masing-masing pesawat yang beroperasi. Dalam melakukan analisis pola pergerakan pesawat, data pokok yang dibutuhkan adalah aircraft performance / flash masing-masing pesawat. Berikut ini adalah contoh flash pesawat kritis yang beroperasi di Bandara Sam Ratulangi Manado. Gambar 6 adalah aircraft performance / flash pada pesawat Boeing 737 - 900.

Analisis ini bertujuan untuk mengetahui kesesuaian kawasan keselamatan operasi penerbangan (KKOP) terhadap topografi sekitar Bandara Sam Ratulangi Manado. Atraksi yang ditawarkan oleh DTW berbentuk pengenalan budaya dan sejarah Kota Surabaya, seperti dari flash Pesawat Boeing 737 - 900 didapatkan perhitungan pola pergerakan pesawat dengan karakteristik yang dapat dilihat pada Tabel 7.

D. Analisis Pola Pergerakan Masing-masing Pesawat terhadap Topografi

Analisis topografi dalam Studi ini dilakukan pengamatan pada penampakan topografi searah dengan approach runway. Gambar 7 merupakan bentuk topografi yang diambil dari tengah runway ke arah runway 36 sepanjang $16.925 \mathrm{~km}$ dan dari tengah runway ke arah runway 18 sepanjang $16.925 \mathrm{~km}$.

Setelah mengetahui elevasi topografi kawasan bandara, dilakukan evaluasi pola pergerakan terhadap topografi. Dilakukan evaluasi terhadap ketinggian pesawat saat lift off terlebih dahulu. Jika elevasi permukaan tanah ditambah dengan jarak ijin ketinggian (10.7 m) antara permukaan tanah dan pesawat memenuhi syarat, maka untuk pola pergerakan pesawat selanjutnya yang lebih tinggi, tidak akan mengganggu keselamatan penerbangan.

Pada Pesawat Boeing 737 - 900 dengan take off

\begin{tabular}{|c|c|c|c|c|c|c|}
\hline \multirow[b]{2}{*}{$\mathrm{NO}$} & \multirow[b]{2}{*}{ Keterangan } & \multicolumn{3}{|c|}{ KOORDINAT } & \multirow[b]{2}{*}{ Wilayah } & \multirow{2}{*}{$\begin{array}{c}\text { Kele } \\
\text { biha } \\
\mathrm{n} \\
\text { Ting } \\
\text { gi } \\
\text { (m) }\end{array}$} \\
\hline & & 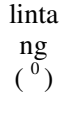 & $\begin{array}{c}\text { bujur } \\
\left({ }^{0}\right)\end{array}$ & $\begin{array}{l}\text { eleva } \\
\text { si } \\
(\mathrm{m})\end{array}$ & & \\
\hline A & Topografi & $\begin{array}{c}1.53 \\
8\end{array}$ & $\begin{array}{c}125.03 \\
7\end{array}$ & 665 & $\begin{array}{c}\text { Horizont } \\
\text { al luar }\end{array}$ & 432 \\
\hline B & Topografi & $\begin{array}{c}1.55 \\
6\end{array}$ & $\begin{array}{c}124.84 \\
1\end{array}$ & 446 & $\begin{array}{c}\text { Horizont } \\
\text { al luar }\end{array}$ & 213 \\
\hline $\mathrm{C}$ & $\begin{array}{c}\text { Manado } \\
\text { Town } \\
\text { Square }\end{array}$ & $\begin{array}{c}1.46 \\
9\end{array}$ & $\begin{array}{c}124.83 \\
0\end{array}$ & 630 & $\begin{array}{c}\text { Horizont } \\
\text { al luar }\end{array}$ & 397 \\
\hline $\mathrm{D}$ & $\begin{array}{l}\text { Ibis Hotel } \\
\text { Manado }\end{array}$ & $\begin{array}{c}1.47 \\
3\end{array}$ & $\begin{array}{c}124.83 \\
3\end{array}$ & 588 & $\begin{array}{c}\text { Horizont } \\
\text { al luar }\end{array}$ & 355 \\
\hline $\mathrm{E}$ & $\begin{array}{l}\text { Aryaduta } \\
\text { Siloam } \\
\text { Manado }\end{array}$ & $\begin{array}{c}1.48 \\
7\end{array}$ & $\begin{array}{c}124.83 \\
7\end{array}$ & 504 & $\begin{array}{c}\text { Horizont } \\
\text { al luar }\end{array}$ & 291 \\
\hline $\mathrm{F}$ & $\begin{array}{c}\text { Swiss } \\
\text { Belhotel } \\
\text { Maleosan }\end{array}$ & $\begin{array}{c}1.48 \\
9\end{array}$ & $\begin{array}{c}124.84 \\
7\end{array}$ & 504 & $\begin{array}{c}\text { Horizont } \\
\text { al luar }\end{array}$ & 291 \\
\hline G & $\begin{array}{c}\text { Hotel } \\
\text { Sintesa } \\
\text { Peninsula }\end{array}$ & $\begin{array}{c}1.49 \\
1\end{array}$ & $\begin{array}{c}124.84 \\
3\end{array}$ & 462 & $\begin{array}{l}\text { Horizont } \\
\text { al luar }\end{array}$ & 229 \\
\hline $\mathrm{H}$ & $\begin{array}{c}\text { Hotel } \\
\text { Aston } \\
\text { Manado }\end{array}$ & $\begin{array}{c}1.49 \\
0\end{array}$ & $\begin{array}{c}124.84 \\
1\end{array}$ & 422 & $\begin{array}{l}\text { Horizont } \\
\text { al luar }\end{array}$ & 189 \\
\hline
\end{tabular}

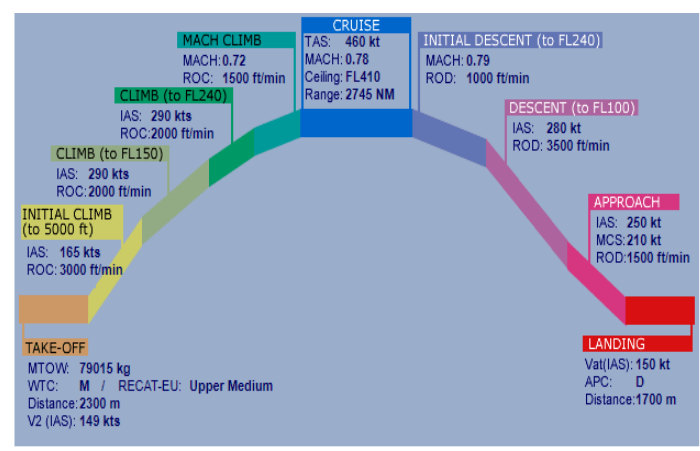

Gambar 6. Flash Pada Pesawat Boeing 737-900.

distance 2300 meter dan mengalami lift off menuju ketinggian $35 \mathrm{ft}(10,7 \mathrm{~m})$ ke arah runway 29-11. Setelah diperhitungkan dan mendapatkan TOR sepanjang 2182.43 meter dengan sudut lift off $5.2^{\circ}$ maka dapat digambarkan seperti yang ditunjukkan pada Gambar 8 . 
Tabel 7. Hasil Perhitungan Pola Pergerakan Pesawat

\begin{tabular}{|c|c|c|c|c|c|c|c|c|c|c|c|}
\hline \multirow{3}{*}{$\begin{array}{c}\text { Boing } \\
737-900\end{array}$} & Tinggi & $\begin{array}{c}\text { Beds } \\
\text { Tingri }\end{array}$ & \multicolumn{3}{|c|}{ IAS } & $\mathrm{ROC}$ & \multicolumn{3}{|c|}{ Jaralk } & \multirow{2}{*}{$\frac{\text { Sudut }}{6}$} & \multirow{3}{*}{\begin{tabular}{|c|} 
Jaralk \\
Total \\
7 \\
$\mathrm{~m}$
\end{tabular}} \\
\hline & 1 & 2 & \multicolumn{3}{|c|}{3} & 4 & \multicolumn{3}{|c|}{5} & & \\
\hline & At & At & kts & mach & fom & fym & $\mathrm{Nm}$ & $\mathrm{ft}$ & $\mathrm{m}$ & degryes & \\
\hline die off & 0 & & 149 & & 15089.0 & & & & 2300 & & 2300 \\
\hline $\begin{array}{l}\text { Initial } \\
\text { Climb }\end{array}$ & 5000 & 5000 & 165 & & 16709.3 & 3000 & 4.58 & 27848.8 & .9 & 0.18 & 10793.9 \\
\hline Climb & & 10000 & 290 & & 29368.0 & 2000 & 24.17 & & & 2.59 & 55579.9 \\
\hline & 24000 & 9000 & 290 & & 29368.0 & 2000 & 21.75 & 21.5 & & 2.59 & 05887.3 \\
\hline $\begin{array}{l}\text { Mach } \\
\text { Climb }\end{array}$ & 41000 & 17000 & & 0.72 & 48230.1 & 1500 & 0 & 550134.3 & 8043.0 & 1.77 & 263930.4 \\
\hline Crise & & & & & 52249.2 & 460 & 2745 & & & 0 & 5351006.2 \\
\hline Initial & 24000 & 17000 & & 0.79 & 52919.1 & 1000 & 0 & 258694.1 & 79020.2 & 3.75 & 5430026.4 \\
\hline Bear. & 10000 & 14000 & 280 & & 28355.3 & 3500 & 18.67 & 13420.8 & 34593.3 & 7.04 & 5464619.8 \\
\hline 800 & 0 & 10000 & 250 & & 25317.2 & 1500 & 27.78 & 168780.9 & 51478.2 & 3.39 & 5516098.0 \\
\hline ding & & & 150 & & 15190.3 & & 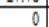 & 0.0 & 1700.0 & & 5517798. \\
\hline
\end{tabular}

Dari Gambar 8 tersebut, garis hijau merupakan topografi permukaan tanah, hitam merupakan garis horizontal sejajar runway bandara, dan merah merupakan garis penerbangan pesawat setelah lift off (angle of attack). Sehingga dapat disimpulkan bahwa pesawat tidak mengalami gangguan keselamatan saat melakukan lift off. Sehingga untuk pola-pola pergerakan pesawat berikutnya, tidak akan mengganggu keselamatan operasional.

\section{E. Pengaruh Berat Pesawat terhadap Ruang Udara}

Pesawat kritis yang beroperasi di BandaraSam Ratulangi adalah Boeing 737- 900. Jarak maksimum yang ditempuh pesawat adalah Bandara Sam Ratulangi Manado - Bandara Shanghai Pudong Tiongkok dengan jarak 1790 nautical miles. Range/jarak yang telah diketahui dimasukkan ke dalam grafik Gambar 9. Dari grafik Gambar 9 dengan range $1790 \mathrm{~nm}$ didapatkan OWE plus payload adalah $61950 \mathrm{~kg}$ dengan Brake Release Gross Weight adalah $77100 \mathrm{~kg}$. OEW boeing $737-900$ adalah $42493 \mathrm{~kg}$. Sehingga payload pada penerbangan ini adalah sebagai berikut.

Payload $=$ OEW plus payload pada grafik - OEW

Payload $=61950-42493 \mathrm{~kg}$

Payload $=19457 \mathrm{~kg}$

Dilakukan juga perhitungan konsumsi bahan bakar pesawat boeing 737-900 pada destinasi Manado Tiongkok sebagai berikut.

Konsumsi fuel $=$ Brake Release Gross Weight - Zero Fuel Weight

Konsumsi fuel $=77100 \mathrm{~kg}-62732 \mathrm{~kg}$

Konsumsi fuel $=15363 \mathrm{~kg}=12325.61$ liter

(Masa jenis avtur $=0.820 \mathrm{~kg} / \mathrm{liter}$

Dengan Take off distance $2182.43 \mathrm{~m}$, maka dapat dilihat pada grafik Gambar 10 bahwa dengan elevasi runway $83 \mathrm{mdpl}$, maka seharusnya Operational Takeoff Weight adalah $70216 \mathrm{~kg}$.

Namun berdasarkan data yang diperoleh, dalam rute penerbangan ini berat pesawat mencapai $170000 \mathrm{lbs}$ $(77100 \mathrm{~kg})$. Sehingga maksimum payload pada penerbangan ini sebagai berikut.

Max Payload $=$ AGW - bahan bakar - OWE

Max Payload $=(70216-15150-42493) \mathrm{kg}$

Max Payload $=12573 \mathrm{~kg}$

Destinasi pesawat dari Bandara Sam Ratulangi menuju Bandara Shanghai Pudong memerlukan waktu 17400s ( 4 jam 50 menit) dengan Boeing 737-900. Dalam radius destinasi $1790 \mathrm{~nm}$ pesawat dapat menghabiskan bahan bakar sebesar 18475.60 liter. Sehingga, konsumsi bahan bakar pesawat per panjang destinasi yag ditempuh adalah 10.32 liter/nautical miles.
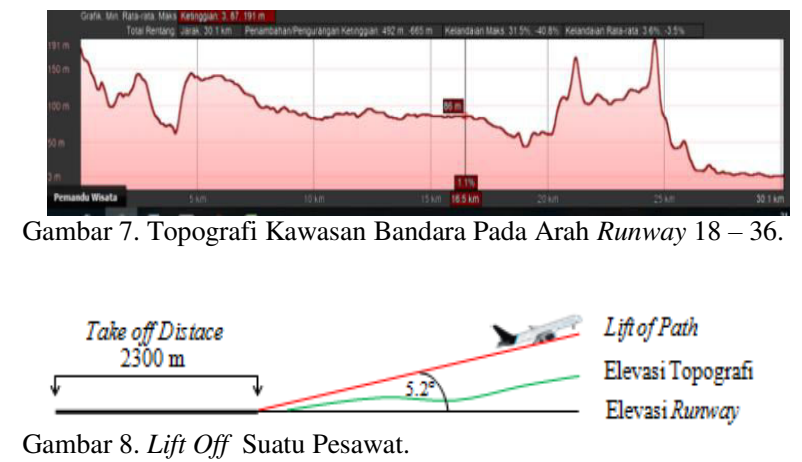

Dalam evaluasi ini, perlu diketahui destinasi optimum dengan komposisi fuel dan payload terbaik dalam operasional pesawat boeing 737- 900. Semakin jauh destinasi suatu pesawat, maka akan semakin besar pula fuel yang dikonsumsi dan semakin berkurang payload dalam pesawat tersebut. Sehingga dibuatlah grafik payload, fuel, dan jarak tempuh optimum.

Gambar 11 menunjukkan bahwa operasional pesawat optimum pada jarak tempuh $1920 \mathrm{~nm}(3555 \mathrm{~km})$ dengan mengkonsumsi bahan bakar sebesar 18720 liter dan payload sebesar $19265 \mathrm{~kg}$. Sehingga destinasi pesawat boeing 737-900 dapat ditambahkan tidak hanya pada radius $1790 \mathrm{~nm}(3315 \mathrm{~km})$ Bandara Sam Ratulangi Manado - Bandara Internasional Pudong Tiongkok melainkan dapat ditambahkan destinasi hingga $1920 \mathrm{~nm}$ ( $3555 \mathrm{~km})$.

\section{F. Penentuan Potensi Rute Tambahan}

Meski Pesawat Boeing 737 - 900 dapat memperpanjang jarak tempuhnya hingga $1920 \mathrm{~nm}$ (3555 $\mathrm{km})$, namun tidak semua rute bandara yang dapat ditempuh direkomendasikan. Rute potensial tambahan untuk penerbangan dari Manado dipilih atas dasar jumlah wisatawan yang datang ke Manado. Seperti pada latar belakang, pada juni 2016 sebelum ada direct flight dari Manado ke Tiongkok, jumlah wisatawan dari Tiongkok hanya 1.427 orang namun setelah dibuka direct flight dari Manado ke Tiongkok pada bulan Juli 2016 jumlah wisatawan naik $312,82 \%$ menjadi 5.148 orang.

Untuk Rute penerbangan langsung dari Amerika, Hongkong, Perancis, Jerman, Inggris, Belanda, India, dan Rusia tidak dapat dibuka karena jarak tempuh dari dan ke Manado melebihi jarak tempuh dari pesawat Boeing 737 - 900 yaitu 3555 km (1920 nm) (Gambar 12). Sehingga potensi rute tambahan yang bisa dioperasikan yang didasarkan pada data wisatawanmancanegara yang potensial berkunjung ke Manado pada Tabel 8.

Rute penerbangan langsung dari Manado ke Korea Selatan juga dapat dibuka melalui Bandara Internasional Jeju, Korea Selatan dengan jarak $1892.5 \mathrm{~nm}$.

Rute penerbangan langsung dari Manado ke Thailand dapat dibuka melalui Bandara Internasional Suvarnabhumi 1867 nm (Gambar 13).

\section{KESIMPULAN}

Hasil dari Studi yang telah disusun ini adalah sebagai berikut.

1. Hasil dari analisis runway terhadap Pesawat yang beroperasi di Bandara Sam Ratulangi Manado menunjukkan bahwa evaluasi panjang dan lebar runway tersedia masih memenuhi. 


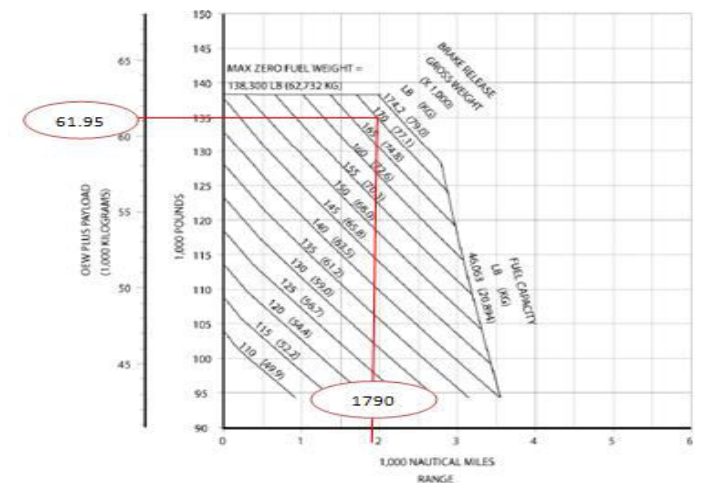

Gambar 9. Grafik Perngaruh Range dan Payload Pesawat Boeing 737 -900 .

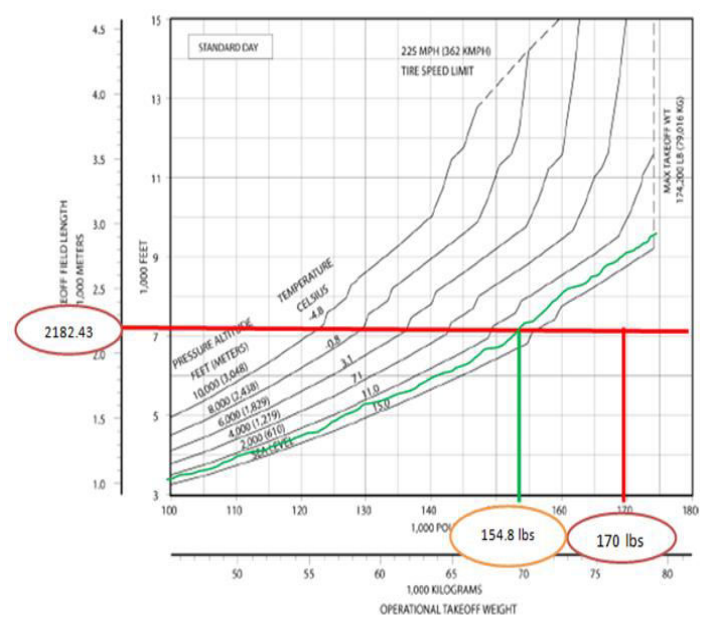

Gambar 10. Grafik Operational Take off Weight untuk Pesawat Boeing 737 - 900.

Sumber : Boeing, 2013

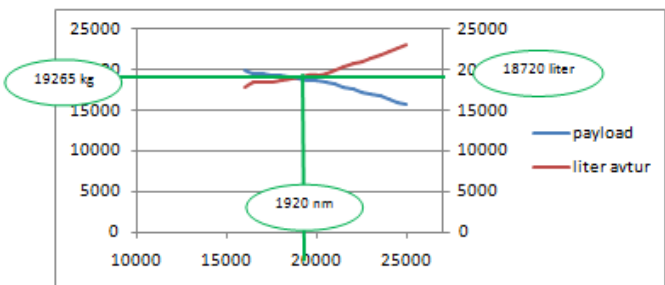

Gambar 11. Grafik Payload, Fuel, dan Jarak Operasional Boeing 737-900.

2. Dari analisis Kawasan Keselamatan Operasi Penerbangan (KKOP) dengan topografi wilayah sekitar Bandara Sam Ratulangi menunjukkan bahwa pada arah memanjang runway, kawasan keselamatan operasi penerbangan Bandara Sam Ratulangi terhadap topografi memenuhi syarat dan tidak menimbulkan masalah. Namun pada arah melintang runway, kawasan operasi penerbangan Bandara Sam Ratulangi terhadap topografi tidak memenuhi, karena elevasi topografi lebih tinggi dari pada elevasi KKOP . Berdasarkan SNI 03-71122005 tentang kawasan keselamatan operasi penerbangan bahwa terhadap bangunan yang berupa benda tidak bergerak yang sifatnya sementara maupun tetap yang didirikan atau dipasang oleh orang atau yang telah ada secara alami, seperti: gedung-gedung, menara, cerobong asap, gundukan tanah, jaringan transmisi, bukit dan gunung yang menjadi penghalang atau obstacle saat ini tetap diperbolehkan sepanjang prosedur keselamatan operasi penerbangan terpenuhi [4].

3. Dari analisis pola pergerakan pesawat ruang udara,menunjukkan bahwa sudut lift off ditentukan

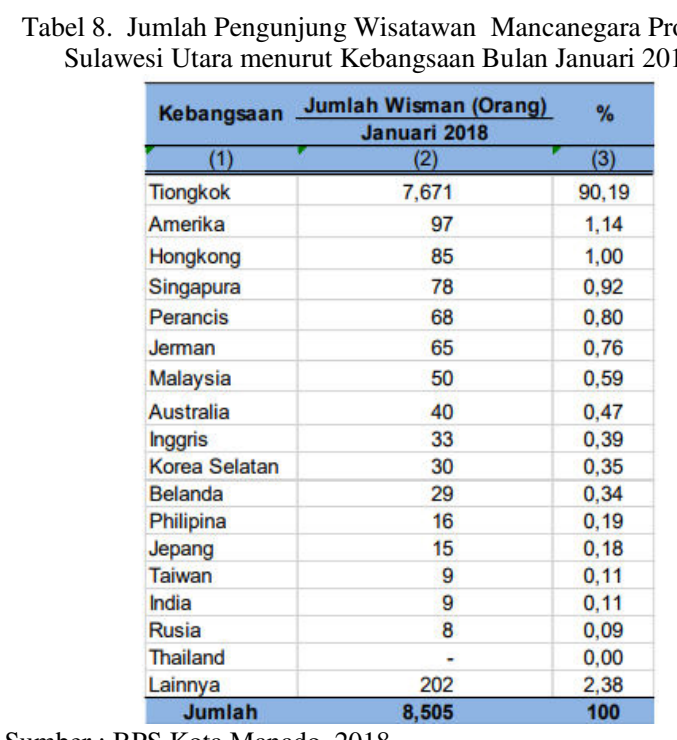

Sumber : BPS Kota Manado, 2018

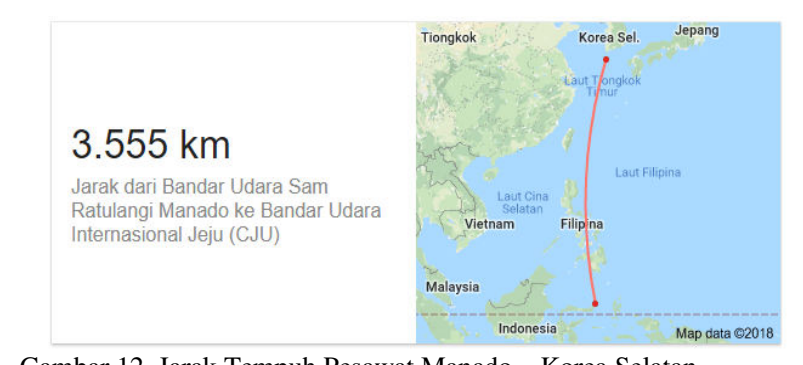

Gambar 12. Jarak Tempuh Pesawat Manado - Korea Selatan.

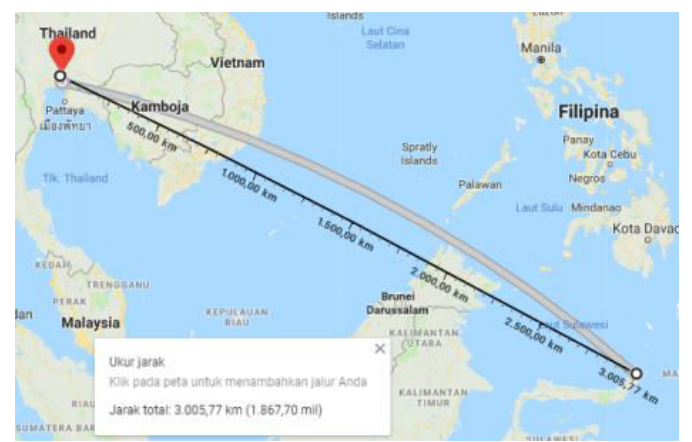

Gambar 13. Jarak Tempuh Pesawat Manado - Thailand.

dengan menggunakan angle of attack untuk mendapatkan take of run sepanjang 2189.21 meter dengan sudut lift off $5.2^{\circ}$. Pada jarak $8 \mathrm{~km}$ dari ujung runway, elevasi muka tanah mencapai $140 \mathrm{~m}$ dari permukaan air laut, dan pada jarak tersebut, pesawat berada pada ketinggian $728 \mathrm{~m}$ diatas permukaan air laut. Maka dapat disimpulkan bahwa pesawat tidak mengalami gangguan keselamatan operasional dan memenuhi jarak ijin pesawat terhadap topografi.

4. Operasional pesawat optimum pada jarak tempuh $1920 \mathrm{~nm}(3555 \mathrm{~km})$ dengan mengkonsumsi bahan bakar sebesar 18720 liter dan payload $19265 \mathrm{~kg}$. Sehingga destinasi pesawat boeing 737-900 dapat ditambahkan tidak hanya pada radius $1790 \mathrm{~nm}$ (Bandara Sam Ratulangi Manado - Bandara Internasional Pudong Tiongkok melainkan dapat ditambahkan destinasi hingga $1920 \mathrm{~nm}(3555 \mathrm{~km})$ dan dapat menambah destinasi ke beberapa bandara sebagai berikut.
a. Bandara Internasional Jeju, Korea Selatan
b. Bandara Internasional Port Hedland, Australia
c. Bandara Internasional Cairns, Australia 
d. Bandara Internasional Darwin, Australia

e. Bandara Internasional Taoyuan, Taiwan

f. Bandara Internasional Ninoy Aquino, Philipina

g. Bandara Internasional Suvarnabhumi, Thailand

h. Bandara Internasional Kuala Lumpur, Malaysia

\section{DAFTAR PUSTAKA}

[1] "PT Angkasa Pura I (Persero)." [Online]. Available: https://ap1.co.id/id/information/internal-magazine. [Accessed: 20-Mar-2019].
[2] Euro COntrol, “Aircraft Performance Database,” 2016. [Online]. Available:

https://contentzone.eurocontrol.int/aircraftperformance/details.as px? ?CAO=A319. [Accessed: 20-Mar-2019].

[3] D. J. P. Udara, Peraturan Direktur Jenderal Perhubungan Udara Nomor: SKEP/77/VI/2005 tentang Persyaratan Teknis Pengoperasian Fasilitas Teknik Bandar Udara. 2005.

[4] D. J. P. Udara, SNI 03-7112-2005. Kawasan Keselamatan Operasi Bandara.Departemen Perhubungan RI. Jakarta, 2004. 